\title{
Seroprevalence of Hepatitis C Virus Infection Among Health Care Workers
}

\author{
S ALAM, N AHMAD, M KHAN, G MUSTAFA, A AL MAMUN, G MASHUD
}

\begin{abstract}
Summary:
Background and aims: Parenteral route is the principal mode of transmission of Hepatitis C Virus $(\mathrm{HCV})$. Health care workers are at risk of infection with $\mathrm{HCV}$. Aim of study was to estimate seroprevalence of HCV amongst health care workers and identify possible risk factors of HCV infection. Materials and Methods: 355 health care workers were selected from July 2005 to June 2006 working in different departments of Bangabandhu Sheikh Mujib Medical University, Dhaka, Bangladesh. Among them $43.5 \%$ were doctors, $32.1 \%$ nurses, $11.8 \%$ ward boys, $5.9 \%$ operation theatre staffs (OT staffs), and $6.8 \%$ others. Sera were tested for HCV antibodies by ELISA. Data
\end{abstract}

\section{Introduction:}

Hepatitis $\mathrm{C}$ virus infection continues to be a major disease burden all over the world. In 1999, WHO estimated a worldwide prevalence of about $3 \%$ with $\mathrm{HCV}$ affecting 170 million people worldwide. ${ }^{1}$ In Asia the figure is $0.3 \%$, in China the figure ranges from $0.5 \%-0.8 \% .{ }^{2}$ However, there is considerable geographical variation in the incidence and prevalence of $\mathrm{HCV}$ infection. Much of the variability between regions can be explained by the frequency and extent to which the risk-factors involved, drug use accounting for $60-80 \%,{ }^{2-5}$ transfusion and transplants $5-13 \%,{ }^{6}$ unsafe injection, other health care related procedure $2-18 \%,{ }^{7}$ occupational exposure $0-7 \%$ and perinatal transmission $0-40 \%{ }^{8-11}$

Generally, most studies of prevalence use blood donors to report frequency of HCV usually by anti$\mathrm{HCV}$ antibodies and do not report follow up $\mathrm{HCV}$ testing. Incidence of $\mathrm{HCV}$ seroconversion after

Shahinul Alam FCPS (Medicine), Nooruddin Ahmad FCPS (Medicine), Mobin Khan FCPS (Medicine), Golam Mustafa MD(Hepatology), Ayub Al Mamun FCPS (Medicine), Golam Mashud MD (Hepatology), Department of Hepatology, Bangabandhu Sheikh Mujib Medical University, Dhaka, Bangladesh.

Address of correspondence: Dr. Md. Shahinul Alam, Assistant Professor, Department of Hepatology, Bangabandhu Sheikh Mujib medical University, Shahbag, Dhaka, Bangladesh. E-mail address: shahinu167@yahoo.com

Received: 20 March, 2007

Accepted: 27 August, 2007 analyzed by SPSS 10.0 version. Results: Mean age was $31.56 \pm 7.4$ years. Males were $51.4 \%$ and females $48.6 \%$. Anti-HCV was positive in 5(1.4\%) cases out of 355. Most prone to HCV infection were nurses (3) followed by doctor (2). No ward boy or OT staff was affected. Previous surgical (80\%) and dental procedures (60\%) were the main risk factors than recipients of blood transfusion (20\%), intravenous drug users (20\%), and multiple sexual exposures (20\%). Conclusions: Nurses are more prone to HCV infection. Surgical procedures are the main risk factors for acquiring HCV infection. Proper sterilization of surgical instruments is recommended.

(J Bangladesh Coll Phys Surg 2007; 25 : 126-129)

accidental needle stick exposure is uncertain, with reports ranging from $0-10 \% .{ }^{12-15}$ Whether health care workers have a higher prevalence of hepatitis $\mathrm{C}$ virus infection through percutaneous occupational exposure than the general population is unclear. ${ }^{2,16-21}$ This study was done to estimate seroprevalence of $\mathrm{HCV}$ infection amongst health care workers and identify possible risk factors of $\mathrm{HCV}$ infection.

\section{Materials and Methods:}

In this study 355 consecutive healthcare workers of different departments of Bangabandhu Sheikh Mujib Medical University Hospital were included for detection of Anti-HCV in their sera. This study was done in the Department of Hepatology, Bangabandhu Sheikh Mujib Medical University, Dhaka, Bangladesh during the period from July 2005 to June 2006. The study populations were of different categories like doctors, staff nurses, ward boys, OT staffs and other categories of staffs (others). They were of either sex with ages ranging from 18 to 56 years.

Before the commencement of the study a well formed questionnaire was prepared consisting of employee's name, sex, date of birth, location of employment, marital status, history of jaundice, blood transfusion, intravenous drug uses, dental procedure, hospital admission, multiple sexual exposures, history of surgery and hepatitis B virus vaccination. For each 
case, after enrollment, $3 \mathrm{ml}$ of blood was collected in a sterile test tube without anticoagulant from anticubital vein with all aseptic precaution. Each case was assured that secrecy will be maintained in case of positive result.

Sera were screened for antibody to HCV by ELISA3. Reagent used was diasorin (Italy). Reactive samples were considered to be positive.

Previous blood transfusion (recipient), dental procedure, surgical procedure were catagorized as the major risk factors and multiple sexual exposures, intravenous drug abuse, alcohol abuse, diabetes mellitus \& tuberculosis as the minor risk factors.

\section{Results:}

Of the 355 health care workers studied, males were $183(51.4 \%)$ and females were 172(48.6\%). Amongst them $148(43.5 \%)$ were doctors, 109 (32.1\%) were staff nurses, 40 (11.8\%) were ward boys, 22 (5.9\%) were OT staffs and $23(6.8 \%)$ were others; $64.6 \%$ were married and $35.4 \%$ were unmarried (Table-1). Among the major risk factors- $46.6 \%$ had history of dental procedure, $31.9 \%$ had history of surgery, $6.8 \%$ had history of blood transfusion (Table-1) and 26.6\%

\section{Table-I}

\section{Demographic profile of study population $(n=355)$.}

\begin{tabular}{lcc} 
Variables & \multicolumn{2}{c}{ Values } \\
\hline Age (Years) & $31.56 \pm 7.41$ (Mean \pm SD) \\
Sex & Males & Females \\
& $51.4 \%$ & $48.6 \%$ \\
Job Status & Doctors & Nurses Others \\
& $43.5 \%$ & $32.1 \% \quad 24.4 \%$ \\
Marital Status & Married & Unmarried \\
& $64.6 \%$ & $35.4 \%$ \\
H/O Jaundice & Present & Absent \\
& $26.6 \%$ & $73.4 \%$ \\
H/O Hospitalization & Present & Absent \\
& $39.8 \%$ & $60.2 \%$ \\
H/O Surgery & Present & Absent \\
& $32.2 \%$ & $67.8 \%$ \\
H/O Blood Transfusion & Present & Absent \\
& $6.8 \%$ & $93.2 \%$ \\
H/O Dental Procedure & Present & Absent \\
& $46.6 \%$ & $53.4 \%$ \\
H/O Multiple Sexual Exposure & Present & Absent \\
& $7.3 \%$ & $92.7 \%$ \\
H/O I/V Drug Abuse & Present & Absent \\
& $4.0 \%$ & $96.0 \%$ \\
\hline
\end{tabular}

had history of jaundice. Among the minor risk factors-7.3\% had multiple sexual exposures, $4 \%$ had I/V drug abuse, $6.2 \%$ had diabetes mellitus, $2.5 \%$ had history of tuberculosis and $1.7 \%$ had history of alcohol intake. Of the 355 health care workers, 159 (44.9\%) were vaccinated against hepatitis B virus.

Of the 355 cases, five (1.4\%) were anti-HCV positive. Among Anti-HCV positive cases, three were staff nurses $(60 \%)$ and two were doctors (40\%) \{Fig.1\}. Of the Anti-HCV positive cases, three were females and two were males; four were married, four had past history of jaundice, four had previous

\section{Table-II}

Demographic profile of Anti-HCV positive patients $(n=5)$.

\begin{tabular}{lcc} 
Variables & \multicolumn{2}{c}{ Values } \\
\hline Age (Years) & $31.67 \pm 4.51$ & (Mean \pm SD) \\
Sex & Males & Females \\
Job Status & 2 & 3 \\
& Doctors & Nurses \\
Marital Status & 2 & 3 \\
& Married & Unmarried \\
H/O Jaundice & 4 & 1 \\
& Present & Absent \\
H/O Hospitalization & 4 & 1 \\
& Present & Absent \\
H/O Surgery & 3 & 2 \\
& Present & Absent \\
H/O Blood Transfusion & 4 & 1 \\
& Present & Absent \\
H/O Dental Procedure & 1 & 4 \\
& Present & Absent \\
H/O Multiple Sexual Exposure & Present & 2 \\
& 1 & Absent \\
H/O I/V Drug Abuse & Present & 4 \\
& 1 & 4 \\
\hline
\end{tabular}

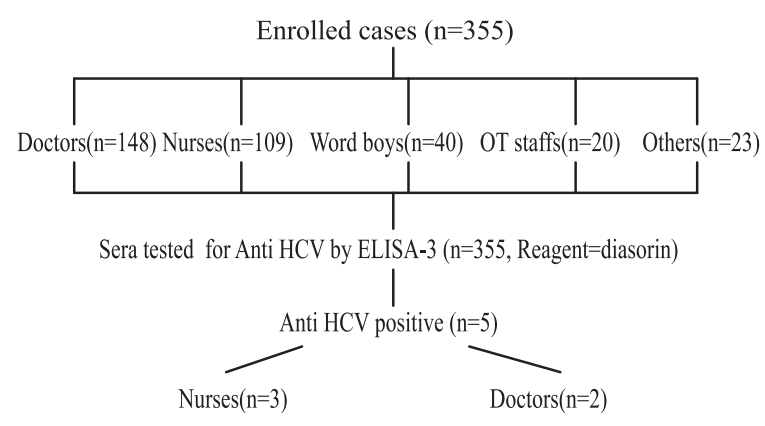

Fig-I: Study design and outcome 
surgery, one had history of previous blood transfusion, three had previous dental procedure (Table-2), two had family history of jaundice, one had history of multiple sexual exposures and one had history of intravenous drug abuse. No OT staff or ward boy was affected. Mean age was $31.67 \pm 4.51$ (Mean $\pm \mathrm{SD}$ ) years. None of them had history of diabetes mellitus or tuberculosis.

In the present study, the prevalence of hepatitis $\mathrm{C}$ virus infection among the health care workers is $1.44 \%$. In present study, history of surgery $(80 \%)$ and history of dental procedures $(60 \%)$ were two main risk factors to be anti $\mathrm{HCV}$ positive among the health workers. History of blood transfusion (20\%), history of multiple sexual exposures (20\%) and I/V drug abuse $(20 \%)$ were the minimum risk factors.

\section{Discussion:}

Hepatitis $\mathrm{C}$ virus infection is the leading issue of concern in health care workers in Bangladesh and abroad. HCV is predominant cause of chronic hepatitis and cirrhosis worldwide and an important factor in the development of hepatocellular carcinoma. HCV infection appears to be endemic in most parts of the world with estimated overall prevalence of $3 \%$, representing approximately 170 million of $\mathrm{HCV}$ affected person world wide. ${ }^{1}$

Dominant mode of transmission is blood to blood contact, the quoted transmission rate is $0-10 \%$ (average 1.8\%) in the situation where health workers sustain a sharp injury from an affected patient ${ }^{22,23}$. While this is less than the comparable figure for hepatitis B virus (HBV) which has a transmission rate of $25-35 \%$, it should be remembered that health care workers can be vaccinated against $\mathrm{HBV}$ but not $\mathrm{HCV}$.

In several investigations on the possibility that $\mathrm{HCV}$ was a major occupational risk to dentists, it was concluded that nosocomial transmission of $\mathrm{HCV}$ in dentistry is possible but relatively unlikely. ${ }^{23-26}$ Health workers who perform exposure prone procedures where injury to the workers may result in exposure of the patients open tissue to the blood of the workers are theoretically of increased risk of infection with blood borne viruses. According to UK health department guidelines, these occupations include surgeons, interventional physicians and intensive care unit and accident and emergency staffs.
A previous study shows seropositivity of $0 \%$ among voluntary blood donors in Dhaka; ${ }^{27}$ this may reflect the average prevalence among general population. The current study shows seroprevalence of $1.44 \%$ among health care workers, which is higher than the general population. The high prevalence of $\mathrm{HCV}$ among health care workers may be due to their exposure to infected blood/blood products of patients with HCV infection. The exposure may in the form of surgical or dental procedures rather than the other routes like accidental needle- pricks, contact of cut skin surface with blood/blood products.

\section{Conclusion:}

Priority should be given to the primary prophylaxis against hepatitis $\mathrm{C}$ infection as there is no pre \& post exposure vaccine against it. Different strategies are required to interrupt different patterns of $\mathrm{HCV}$ transmission. This study on randomly selected health care workers has helped in identifying predominant mode of transmission of the virus as being surgical/dental procedures in the studied population but require further study in this regard. Proper sterilization of surgical/dental instruments should be the main strategy to interrupt the transmission of hepatitis $\mathrm{C}$ virus infection.

\section{References:}

1. WHO. Global surveillance and control of hepatitis C. Report of a WHO consultation organized in collaboration with the Viral Hepatitis Prevention Board, Antwerp, Belgium. J Viral Hepat 1999;35-47.

2. Thomas DL, Gruninger SE, Siew C, et al. Occupational risk of hepatitis $\mathrm{C}$ infections among general dentists and oral surgeons in North America. Am J Med 1996;100:41-45.

3 Leung N W Y, Leung J C K, Tam J S, et al. Does hepatitis C virus infection contribute to hepatocellular carcinoma in Hong Kong. Cancer 1992; 70: 40-44.

4 Alter MJ, Kruszon-Moran D, Nainan OV, et al. Prevalence of hepatitis C virus in the United States. N Engl J Med 1999; 341: 556-562.

5. Farrell GC, Weitman M, Dingley J, Lin R. Epidemiology of hepatitis $\mathrm{C}$ virus infection in

Australia. Gastroenterol Jpn 1993;28 (suppl 5):32-36.

6. Alter MJ. Epidemiology of hepatitis $\mathrm{C}$ virus in the West. Semin Liver Dis 1995;15: 5-14.

7. Alter MJ, Coleman PJ, Alexander WJ, et al. Importance of heterosexual activity in the transmission of hepatitis $\mathrm{B}$ and non-A non-B hepatitis. JAMA 1989; 262:1201-1205. 
8. Lodi G, Portar SR, Teo C, Scully C. Prevalence of HCV infection in health care workers of UK dental hospital. Vr Dental J 1997; 183:329-232.

9. Aizaki H, Saito A, Kusakawa I, et al. Mother to child transmission of hepatitis $\mathrm{c}$ virus variants with an insertional mutation in it's hypervariable region. J Hepatol 1996; 25:608-613

10. Catalano D, Pollio F, Ercolano S, et al. Maternal-fetal transmission of $\mathrm{HCV}$. Role of HIV as a risk factor. Min Gynacol 1999;51:117-119.

11. Fischler B, Lindh G, Lindgren $\mathrm{S}$, et al. Vertical transmission of hepatitis C virus infection. Scand J Infect Dis 1996; 28:353-356.

12. Kiyosawa K, Sodeeyama T, Tanaka E, et al. Hepatitis C in hospital employees with needlestick injuries. Ann Intern Med 1991;115:367-9.

13. Mitsui T, Twano K, Masuko K, et al. Hepatitis $\mathrm{C}$ virus infection in medical personnel after needlestick accident. Hepatology 1992;16:1109-14.

14. Lanphear BP, Linnemann CC Jr, Cannon CG, et al. Hepaitis $\mathrm{C}$ virus infection in health care workers: risk of exposure and infection. Infect Control Hosp Epidemiol 1994;15:745-50.

15. Puro V, Petrosillo N, Ippolito G. Italian Study Group on Occupational Risk of HIV and Other Blood borne Infection. Risk of hepatitis $\mathrm{C}$ seroconversion after occupational exposures in health care workers. Am J Infect Control $1995 ; 23: 273-7$

16. Zuckerman J, Clewley G, Griffiths P, et al. Prevalence of hepatitis $\mathrm{C}$ antibodies in clinical health care setting. Lancet 1994; 343:1618-20.

17. Neal KR, Darman J, Irving WL. Prevalence of hepatitis C antibodies among health care workers of two teaching hospitals. Who is at risk? BMJ 1997;314:179-80.
18. Thomas DL, Factor SH, Kelen GD, et al. Viral hepatitis in health care personnel of the Johns Hopkins Hospital. Arch Intern Med 1993; 153:1705-12.

19. Cooper BW, Krusell A, Titlton RC, et al. Seroprevalence of antibodies of hepatitis $\mathrm{C}$ virus in high risk hospital personnel. Infect Centrol Hosp Epidemiol 1992;13:82-5.

20. Panlilio AL, Shapiro CN, Schable CA, et al. Serosurvey of human immunodeficiency virus, hepatitis $\mathrm{B}$ virus and hepatitis $\mathrm{C}$ virus infection among hospital based surgeons. J Am Coll Surg 1995;180:16-24.

21. Shapiro CN, Tokars JI, Chamberland ME, and the American Academy of Orthopedic Surgeons Serosurvey Study Committee. Use of hepatitis B vaccine and infection with hepatitis B and C among orthopedic surgeons. J Bone Joint Surg 1996;78-A: 1791-800.

22. Alter MJ, Mast EE, Moyer LA, Margolis HS, Hepatitis C. Infect Dis Clin North Am 1998;12:13-26.

23. Molinari JA. Hepatitis C virus infection. Dent Clin North Am 1996;40:309-325

24. Porter SR, Lodi G. Hepatitis C virus (HCV) - an occupational risk to dentists? Br Dent J 1996;180:473-474.

25. Epstein JB, Sherlock CH. Hepatitis C: rapid progress in medicine and implications for dentistry. J Can Dent Assoc 1994;60:323-329.

26. Thomas DJ, Gruninger SE, Siew C, et al. Occupational risk of hepatitis $\mathrm{C}$ infections among general dentists and oral surgeons in North America. Am J Med 1996;100:41-45.

27. Irshad M, Acharya S K, Joshi Y K. Prevalence of hepatitis $\mathrm{C}$ in the general population and in the selected group of patients in Delhi. Ind J Med Res 1995;102:162-64. 